
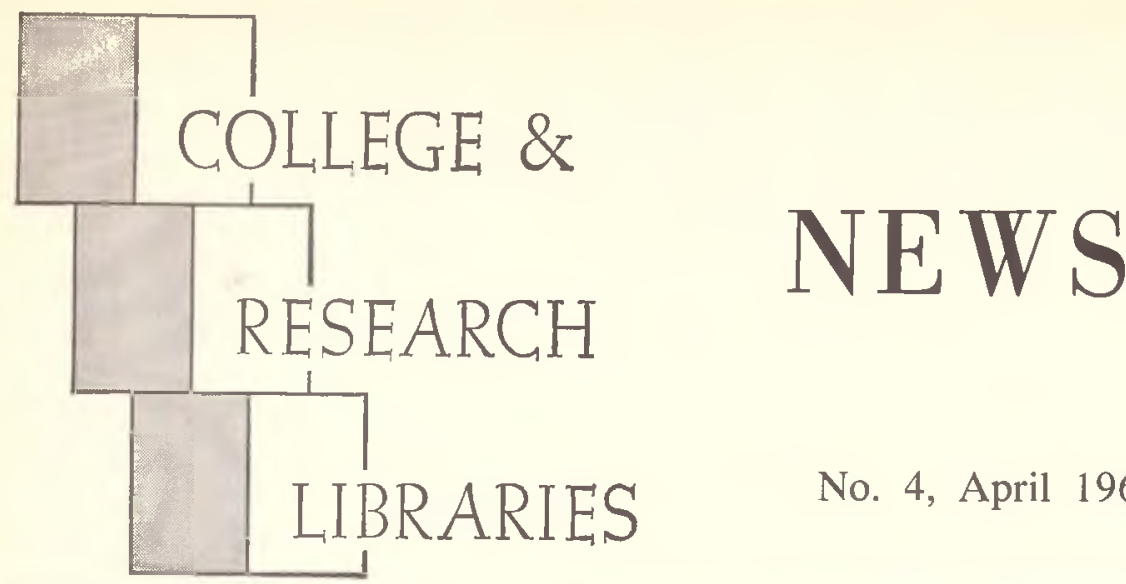

No. 4, April 1968

ACRL News Issue (B) of College \& Research Libraries, Vol. 29, No. 2

\title{
Schedule of Meetings
}

\section{Annual Conference \\ Kansas City, Missouri \\ June 23-29, 1968}

The following schedules are tentative. Meetings will be held in the Municipal Auditorium and nearby hotels. A final schedule, with locations, will be mailed by Mary Cilluffo, Assistant for Conference Arrangements, to officers and chairman of all ALA groups. Each chairman should notify concerned members of his activity.

Program meetings. For details, refer to page 92 of this issue. Other details will appear in the ALA Bulletin, May 1968.

\section{Preconferences}

College Libraries Section-Non-Western Resources Committee

Thursday-Saturday, June 20-22, University of Kansas, Lawrence

Junior College Libraries Section

Wednesday-Saturday, June 19-22, Chase-Park Plaza Hotel, St. Louis

Rare Books Section

Thursday-Saturday, June 20-22, Dixon Inn, Muehlebach Hotel and Linda Hall

Conference Programs

ACRL Membership and Program

Monday, June 24, 10:00 a.m.-12 noon

Committee on Library Services

Monday, June 24, 4:30-6:00 p.m.
College Libraries Section

Tuesday, June 25, 2:00-4:00 p.m.

(See also Preconferences)

Junior College Libraries Section

Tuesday, June 25, 12 noon-Luncheon

Tuesday, June 25, 2:00-4:00 p.m.

(See also Preconferences)

Rane Books Section

(See Preconferences)

Subject Specialists Section

(Program cosponsored by L\&PS and S\&EE Subsections)

Agricultural and Biological Sciences SUBSECTION

Monday, June 24, 4:30-6:00 p.m.

Art Subsection

Tuesday, June 25, 2:00-4:00 p.m.

(Tour)

Law and Political Science Subsection, and

Slavic and East European Subsection

Tuesday, June 25, 2:00-4:00 p.m.

Education and Behavional Sciences SubSECTION

Tuesday, June 25, 4:30-6:00 p.m.

UNIVERSITY LiBRARIES SECTION

Tuesday, June 25, 8:30-10:00 p.m.

Extension Library Services Committee

Tuesday, June 25, 2:00-4:00 p.m.

Urban University Libraries Committee Tuesday, June 25, 2:00-4:00 p.m. 


\section{YOU CAN BANK ON}

for

better

Taylor-Carlisle

BOOKSELLERS TO THE ACADEMIC WORLD

service

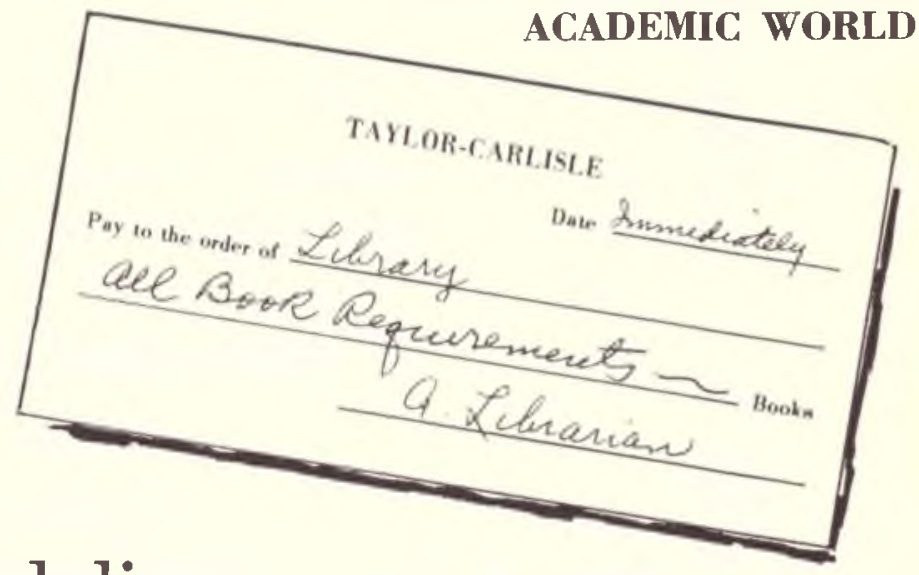

Speedy delivery

... your orders processed without delay

Efficient service

... alert, experienced personnel

Huge inventory

... in our own warehouses

Send for Our Current Discount Schedule

Taylor-Carlisle

NEW YORK: 115 East 23rd Street

New York, N.Y. 10010

FLORIDA : Winter Park Mall

Winter Park, Florida 


\section{Business Meetings}

ACRL BOARD OF DIRECTONS

Monday, June 24, 2:00-4:00 p.m.

Wednesday, June 26, 10:00 a.m.-12 noon

ACRL COMMITTEES

Audio-Visual Committee

Tuesday, June 25, 4:30-6:00 p.m.

Wednesday, June 26, 8:30-9:30 a.m.

Committee on Community Use of Academic Libraries

Tuesday, June 25, 4:30-6:00 p.m.

Thursday, June 27, 10:00 a.m.-12 noon

Committee on Cooperation with

Educational and Professional

Organizations

Monday, June 24, 12 noon-Luncheon

Committee on Grants

Thursday, June 27, 8:00-9:30 a.m.

Committee on Legislation

Tuesday, June 25, 4:30-6:00 p.m.

Committee on Liaison with Accrediting Agencies

Monday, June 24, 8:30 p.m.

Committee on Library Services

Tuesday, June 25, 8:30-9:30 a.m.

Committee on Library Surveys

Monday, June 24, 8:30-10:00 p.m.

National Library Week Committee

To be scheduled

Planning and Action Committee

Sunday, June 23, 2:00-4:00 p.m.

Tuesday, June 25, 4:30-6:00 p.m.

Publications Committee

Thursday, June 27, 8:00-9:30 a.m.

Ad Hoc Committee on Relations with ARL

To be scheduled

Committee on Standards

Monday, June 24, 8:30-10:00 p.m.

Monday, June 24, 2:00-4:00 p.m. (Junior College)

Monday, June 24, 4:30-6:00 p.m. (College)

\section{ACRL Publications, Editorial Boards \\ CHOICE}

Thursday, June 27, 10:00 a.m.-12:00 noon

\section{College and Research Libraries}

Monday, June 24, 4:30-6:00 p.m.

Monograph Series

Wednesday, June 26, 12:00 noonLuncheon

ACRL Membership February 29, 1968 13,327 ACRL Membership February 28, 1967 12,036 ACRL Membership February 28, 1966 10,509

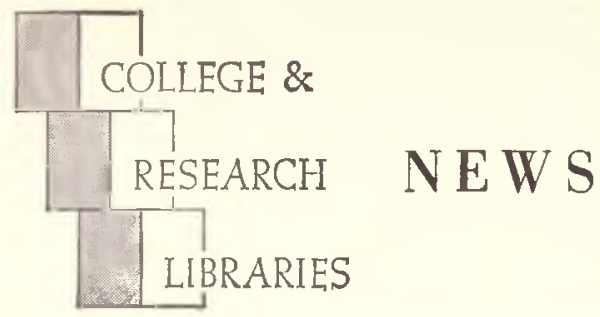

ACRL News Issue of College \& Research Libraries

Editor, David Kaser, Joint University Libraries, Nashville, Tenn. 37203.

Publications Officer, Mary Falvey, 50 E. Huron St., Chicago 60611.

ACRL Executive Secretary, George M. Bailey.

ACRL Officers, 1967/68: President, James Humphry III; College Libraries Section Chairman, Audrey North; Junior College Libraries Section, Mrs. Alice B. Griffith; Rare Books Section, Lawrence S. Thompson; Subject Specialists Section, Richard L. Snyder; Agriculture and Biological Sciences Subsection, Mrs. Pauline W. Jennings; Art Subsection, James K. Dickson; Law and Political Science Subsection, Morris Cohen; Slavic and East European Subsection, Jerzy (George) J. Maciuszko; University Libraries Section, Stuart Forth.

Editorial Board: John M. Dawson, University of Delaware; Gustave A. Harrer, Boston University; SamUEL RothsteIN, University of British Columbia; James E. Skippen, Princeton University; Nomman E. Tanis, Kansas State College of Pittsburg; Maurice F. Tauner, Columbia University; Erreen ThonNton, Oberlin College.

News from the Field, Personnel profiles and notes, classified advertising, official matter of ACRL, and other material of a timely nature is published in the News issues of College of Research Libraries.

Inclusion of an article or advertisement in $C R L$ does not constitute official endorsement by ACRL or ALA.

Production and Advertising and Circulation office: 50 E. Huron St., Chicago, Ill. 60611. Change of address and orders for subscriptions should be addressed to College of Research Libraries, for receipt at the above address, at least two months before the publication date of the effective issue.

Subscription to $C R L$ is included in membership dues to $A C R L$ of $\$ 6$ or more; other subscriptions to $C R L$ are $\$ 10$ per year. Neither subscriptions nor memberships include miscellaneous unscheduled supplements, which are available by purchase only. Retroactive subscriptions are not accepted. Single journal copies are available at $\$ 1.50$ each and News issues at $\$ 1.00$ each from ALA Publishing Department.

Indexed in Library Literature. Abstracted in Library Science Abstracts. Book reviews indexed in Book Review Index.

College \& Research Libraries, is the official journal of the Association of College and Research Libraries, a division of the American Library Association; and is published seventeen times per year-bi-monthly as a technical journal with 11 monthly News issues, combining July-August-at 1201-05 Bluff St., Fulton, Mo. 65251.

Second-class postage paid at Fulton, Mo. and at additional mailing offices. 
ACRL Sections and Subsections

College Libraries Section

Monday, June 24, 4:30-6:00 p.m.

Committee on Non-Western Resources

Saturday, June 22, 4:00-10:00 p.m.

Sunday, June 23, 4:30-6:00 p.m.

Junior College Libraries Section

Tuesday, June 25, 2:00 p.m.

Committee on Instruction and Use

To be scheduled

Ad Hoc Committee on Instructional Materials Center

Sunday, June 23, 4:30-6:00 p.m.

Special Projects Committee

Monday, June 24, 4:30-6:00 p.m.

Subject Specialists Section

Tuesday, June 25, 12 noon-2:00 p.m.Luncheon

Agricultural and Biological Sciences Subsection

Tuesday, June 25, 4:30-6:00 p.m.

Art Subsection

(See Program Schedule)

Law and Political Science Subsection

(See Program Schedule)

Education and Behavioral Sciences

Subsection
(See Program Schedule)

Slavic and East European Subsection

Monday, June 24, 4:30-6:00 p.m.

University Libraries Section

Monday, June 24, 8:30-9:30 a.m.

Wednesday, June 26, 8:30-9:30 a.m.

Ad Hoc Academic Status Committee

Sunday, June 23, 2:00-4:00 p.m.

Committee on Extension Library

Service

(See Program Schedule)

Urban University Libraries Committee

Tuesday, June 25, 8:00-9:30 a.m.

\section{PROGRAM MEETINGS}

Monday, June 24, 10:00 a.m.-ACRL Business meeting.

"Report of the National Advisory Commis. sion on Libraries-Implication for Academic and Research Libraries," Dan M. Lacy, McGraw-Hill Book Company; member, National Advisory Commission on Libraries.

Implications for Accrediting Agencies, Standards, Surveys-Reactor panel speakers to be announced.

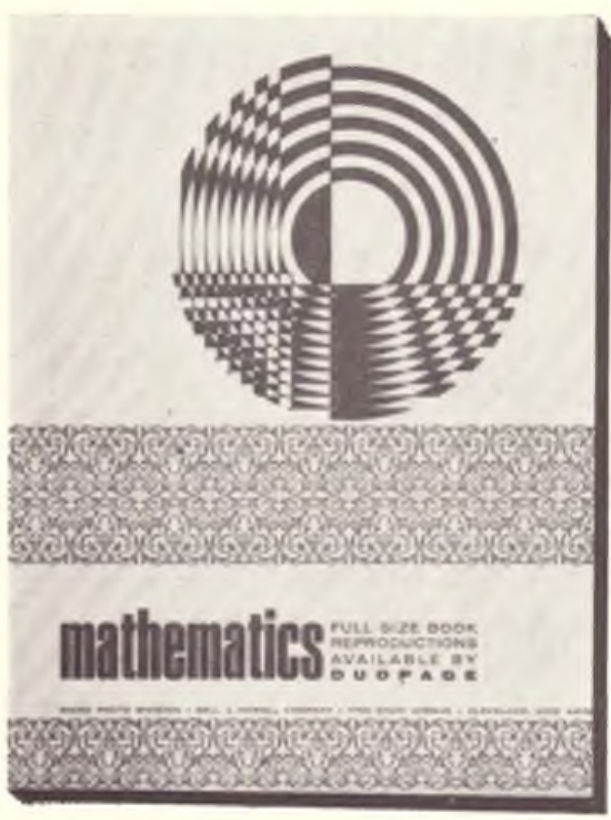

WRITE TODAY FOR FREE CATALOG.

\section{川 \\ mathemalics books \\ REPRODUCED FULL-SIZE BY \\ DUOPAGE}

Send for 32-page catalog listing

out-of-print mathematics books

available in many languages.

Catalog alsoincludesinformation

on how you can now obtain the

other hard-to-get books you need.

\section{mICRO PHOTO DIVISIOI}

1700 SHAW AVE. CLEVELAND, OHIO 44112

\section{- BelleHowell}


ACRL Libhary Senvices Commitee Program

(Cosponsored by Reference Services Division/RTSD Acquisitions Section)

Monday, June 24, 4:30 p.m.- "The Bibliographer in the Academic Library"-Robert Haro, Institute of Governmental Affairs, University of California, Davis.

Reactor panel members: Helen M. Welch, University of Illinois, Urbana; Alan R. Taylor, African Studies, Indiana University, Bloomington; William $H$. Kurth, Washington University Libraries, St. Louis. Moderator, William H. Kurth.

aCRL College Libraries Section Program

Tuesday, June 25, 2:00 p.m.-CLS Business meeting.

"Interinstitutional Systems and the College Library: A Forward Look"-Introduction, Audrey North.

"Contributions of Regional Computorization to Small Colleges"-Frederick G. Kilgour, Ohio College Library Center, Ohio State University, Columbus.

"The Role of the College Library in the 3-R's Systems"-E. J. Josey, Division of Library Development, University of the State of New York, Albany.

Summary and remarks-Robert W. Evans, Oberlin College Library, Ohio.

ACRL Junior College Libraries Section Program

Tuesday, June 25, 12:00 noon-Luncheon.

Tickets at the ALA Central Ticket Desk.

"Implications of the Report of the National Advisory Commission on Libraries for Junior College Libraries"-Robert Deily, Library Services, State University of New York, Albany.

Reports on Activities of Interest to JCLS members.

Business meeting

ACRL Subject Specialists Section Program

(Cosponsored by the ACRL/SSS Law and Political Science Subsection and ACRL/ SSS Slavic and East European Subsection.)

Tuesday, June 25, 2:30 p.m.-“"Advances in Soviet Librarianship and Legal Bibliography."

"Continuity and Change in Russian Librarianship"-Ray R. Suput, Case Western
Reserve University Libraries, Cleveland, Ohio.

"Bibliographic Sources in Soviet Law"Vaclav Mostecky, Foreign Law Reference, Harvard Law School Library, Cambridge, Mass.

Thursday, June 27, 2:00 p.m.

(Program Cosponsored by SSS and Music Library Association)

ACRL/SSS Agriculture and Biological Sciences Subsectron Program

Monday, June 24, 4:30 p.m.- "The Agricultural-Biological Information Network" - Joseph Becker, Director of Information Science, Interuniversity Communications Council (EDUCOM), Washington, D.C.

ACRL/SSS Education and Behavioral Sciences Subsection Program

Tuesday, June 25, 4:30 p.m.-Library Services for Education and Behavioral Sciences-an organization meeting.

Panel members to be announced.

ACRL/SSS Art Subsection Program

Monday, June 24, 4:30 p.m.- "The Cultural Circulation System in the Heart of

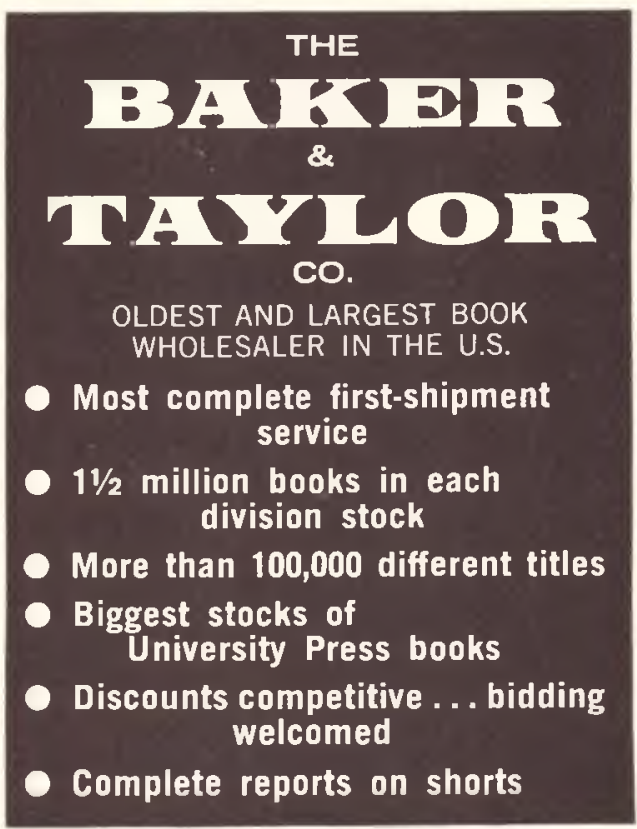

Order from nearest warehouse:

DIVISION ADDRESSES: Hillside, N.J. 07205 - Momence, III., 60954 - Reno, Nev. 89502 - School Center, 50 Kirby Ave, Somerville, N.J. 08876 - Interstate Library Service (subsidiary) 4600 N. Cooper, Okla. City, 73118 


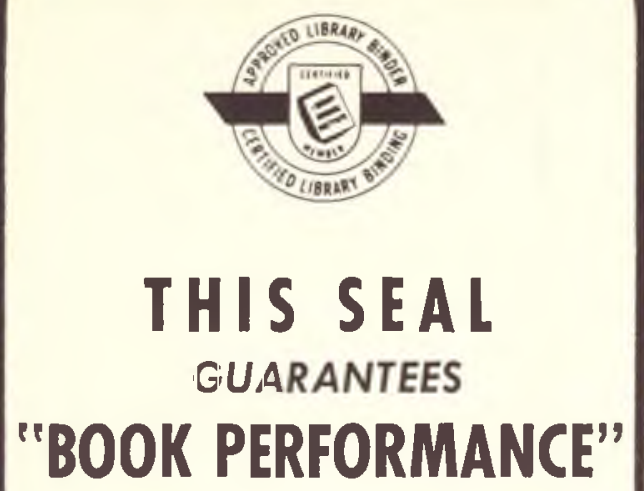

You may ask, "How does one measure performance?" - By quality, of course! The better the quality, the greater the performance.

Whether you order prebound new books or rebinding of worn ones, you just can't get better binding than that you get from your CERTIFIED LIBRARY BINDER. As a member of the Library Binding Institute he is pledged to adhere to the standards of quality formulated by experts who know how library books should be bound.

For maximum performance insist on a binder who displays the LBI seal and who provides a warranty to protect your investment.

Without this seal you have no assurance that your book has been truly library bound.

Be well-informed. Write today for free literature. There is no obligation.

\section{LIBRARY BINDING INSTITUTE} 160 State Street Boston, Massachusetts 02109
America"-Andrew W. Morgan, president, Kansas City Art Institute.

Business meeting

"Far Eastern Books on Art-Ancient and Modern"-Laurence C. Sickman, director, William Rockwell Nelson Gallery, Kansas City, Mo.

Tour of Gallery

ACRL/SSS Law and Political Science Subsection Program

(Cosponsored by the ACRL Subject Specialists Section and ACRL/SSS Slavic and East European Subsection. See ACRL Subject Specialists Section.)

Tuesday, June 25, 2:00-2:30 p.m.-Business meeting.

ACRL/SSS Slavic and East European Subsection Program

(Cosponsored by the ACRL Subject Specialists Section and ACRL/SSS Law and Political Science Subsection. See ACRL Subject Specialists Section.)

Tuesday, June 25, 2:00-2:30 p.m.-Business meeting.

ACRL University Libraries Section Programs

Tuesday, June 25, 8:30 p.m.- "Standards for University Libraries-Proposals, Problems, and Prognosis"-Speakers to be announced.

ACRL/ULS Extension Library Service Committee Program

Tuesday, June 25, 2:00 p.m.- “Organizing an Urban Intelligence System to Meet the Needs of Policy Makers at the Metropolitan and Regional Levels of Decision Making"-John Osman, senior fellow, The Brookings Institution, Washington, D.C.

ASRL/ULS UhbaN UNIVERsities LibrakY CoMmitTeE Program

Tuesday, June 25, 2:00 p.m.

"Role of the Academic Library in Urban Development"--J. Martin Klotsche, chancellor, University of Wisconsin-Milwaukee and president, Association of Urban Universities

\section{PRECONFERENCE MEETINGS}

Non-Western Materials for Undergraduate Collections-Institute sponsored by the 
ACRL College Libraries Section, NonWestern Resources Committee.

University of Kansas, Lawrence

Thursday, June 20, 3:00 p.m., to Saturday, June 22, 2:00 p.m.

Registration fee, $\$ 45.00$, includes dinner on Thursday and Friday, lunch on Saturday, and bus transportation to Kansas City on Saturday. Advance registration is required and limited. Registrations will not be accepted after June 15. Registration forms are available from the ACRL Office, ALA Headquarters. Housing forms will be provided with registration material.

Thursday, June 20, 3:00 p.m.-Registration and Social hour.

Thursday, June 20, 6:30 p.m.-Dinner.

"Non-Western Studies in the Liberal Arts Colleges: Historical Framework"-Audrey North, School of Library Science, Syracuse University, New York.

Friday, June 21, 8:30 a.m.-"African Resources"-Conrad Reining, Catholic University of America, Washington, D.C.

"Asian Resources"-Donald F. Jay, Chief Overseas Operation Division, Library of Congress, Washington, D.C.

Friday, June 21, 10:30 a.m.-“Near Eastern Resources"-David H. Partington, New East Bibliographer, University of Michigan, Ann Arbor.

Friday, June 21, 2:00 p.m.-Working Sessions.

South and South East Asia

Faculty leader: Jean Grossholtz, Associate Professor, Mt. Holyoke College, South Hadley, Mass.

Discussion leaders: Dorothy M. Drake, Librarian, Scripps College, Clarmont, Calif.

Anne C. Edmonds, Librarian, Mount Holyoke College, South Hadley, Mass.

Floyd Merritt, Administrative Assistant, Amherst College, Amherst, Mass.

East Asia

Faculty leader: Donald Gillin, Professor, Duke University, Durham, N.C.

Discussion leaders: Robert W. Evans, Associate Librarian, Oberlin College, Oberlin, Ohio.

Evan I. Farber, Librarian, Earlham College, Richmond, Ind.

Mother O'Connor, Librarian, Manhattanville College of the Sacred Heart, Purchase, N.Y.
Friday, June 21, 6:30 p.m.-Dinner

"International Education Act"--Stanley Wilcox, Chief, Institutional Assistance Section, U.S. Office of Education, Washington, D.C.

Saturday, June 22, 8:30 a.m.-Working sessions.

Middle East and North Africa

Faculty leader: Mrs. Carla J. Klausner, Assistant Professor, University of Missouri at Kansas City, Mo.

Discussion leaders: Charles M. Adams, Librarian, University of North Carolina at Greensboro.

Jean P. Black, Librarian, Portland State College, Portland, Ore.

David T. Wilder, Director of Libraries, University of Manitoba, Winnepeg, Canada.

Sub-Saharan Africa

Faculty leader: Andre Nitecki, Assistant Professor, School of Library Science, Syracuse University, Syracuse, N.Y.

Discussion leaders: H. Vail Deale, Librarian, Beloit College, Beloit, Wis.

\section{FOR THE RUSSIAN BOOK SECTION}

\section{Reference and}

\section{Source Material}

- Russian Literature: Classics, Contemporary

- Linguistics and Literary Criticism

- English-Russian and Russian-English Dictionaries

- Russian Language Records, Folk Songs and Dramatic Readings

- Children's Literature

- Books on Art

- Books on Science

- Textbooks on mathematics, geography, natural sciences, history, etc.

- Socio-Economic Literature

- Russian Atlases and Maps

- Soviet Magazines and Newspapers

Inquire about our out-of-print books and back issue magazines.

Write for Catalogs \& Prices

Phone 212 CH 2-4500

FOUR BOHTIKENT BOOK BORP. DEPT. 727, 156 FIFTH AVENUE, NEW YORK, N. Y. 10010 


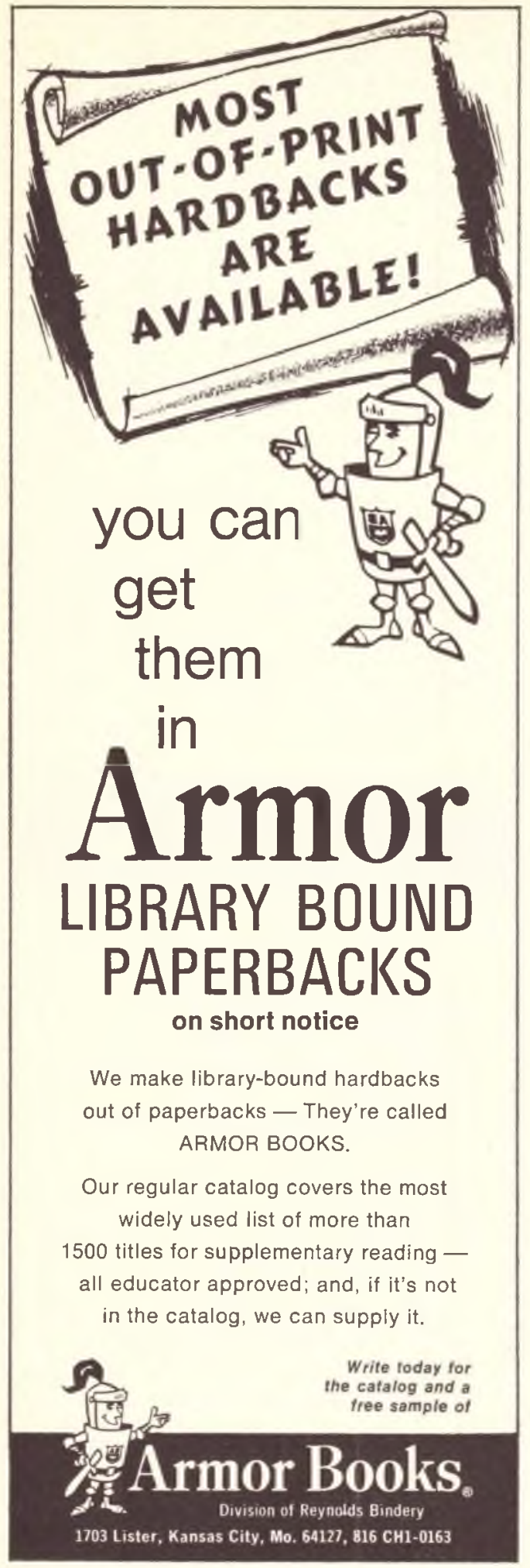

Nancy Divine, Reference Librarian, Mount Holyoke College, South Hadley, Mass.

Kenneth LaBudde, Director of Libraries, University of Missouri at Kansas City, Kansas City, Mo.

Saturday, June 22, 12:00 noon-Luncheon.

"Publishing in Asia and Africa"-Eugene

De Benko, Associate Professor, Divisional

Librarian, International Collection, Michigan State University, East Lansing.

Library Services to Vocational-Technical Education Programs in Junior College Libraries-Institute cosponsored by the ACRL Junior College Libraries Section/ American Association of Junior Colleges.

Chase-Park Plaza Hotel, St. Louis, Mo.

Wednesday, June 19, 3:00 p.m., to Saturday, June 22, 12:00 noon.

Registration fee, $\$ 35.00$, includes dinner on Thursday, box lunch on Friday, and tour. Advance registration is required and limited. Registrations will not be accepted after June 15. Registration forms and housing forms are available from the ACRL Office, ALA Headquarters.

Position papers will attempt to identify the problems in the three major areas of concern-materials, personnel, communication. These papers will point out special problems and will suggest, in broad terms, directions toward possible solutions to the problems.

Materials-Marie T. Mills, vice president, Instruction, Mt. San Antonio College, Walnut, Calif.

Personnel-Clyde E. Blocker, president, Harrisburg Area Community College, Pa.

Communication-James L. Wattenbarger, director, Institute of Higher Education, University of Florida, Gainesville.

Wednesday, June 19, 3:00 p.m.-Registration.

Wednesday, June 19, 5:00-6:30 p.m.-Reception.

Wednesday, June 19, 5:00-8:00 p.m.Multi-media presentation.

Thursday, June 20, 9:00 a.m.-General Session.

Keynote address-Kenneth G. Skaggs, coordinator, Occupational Education Project, American Association of Junior Colleges, Washington, D.C.

Thursday, June 20, 11: a.m.-Panel discussion. 
Materials-Basil Mitchell, director, Southeastern New York Library Resources Council, Poughkeepsie, N.Y.

Personnel-Mrs. Alice B. Griffith, Mohawk Valley Community College, Utica, N.Y. Communication-Mrs. Mayrelee Newman, El Centro College of the Dallas County Junior College District, Dallas, Texas.

Thursday, June 20, 2:00-4:30 p.m.-Small group discussions.

Thursday, June 20, 6:00-7:30 p.m.-Dinner. Speaker: Peggy A. Sullivan, project director, Junior College Library Information Center, ALA.

Friday, June 21, 9:00-11:30 a.m.-Small group discussions.

Friday, June 21, 12:00 noon-4:30 p.m.Tours of three St. Louis Junior College District campuses-box lunch.

Friday, June 21, 7:30-10:00 p.m.-Individual consultant conferences.

Saturday, June 22, 10:00 a.m.-Summary -Rodney Berg, president, College of Dupage, Glen Ellyn, Ill.

The Antiquarian Book Trade in the Twentieth Century-Institute sponsored by the ACRL Rare Books Section.

Linda Hall Library and Muehlebach Hotel

Thursday, June 20, 2:00 p.m., to Saturday, June 22, 12:00 noon.

Registration fee, $\$ 40$, includes dinner on Thursday, luncheon and dinner on Friday, and local bus transportation during the meeting. Advance registration is required and limited. Registrations will not be accepted after June 15. Registration forms are available from the ACRL Office, ALA Headquarters. Make your hotel reservation by using the housing postcard form in the January 1968 ALA Bulletin, p. 75. Request housing in the Dixon Inn.

Thursday, June 20, 3:00 p.m.-Registration. Exhibition.

Thursday, June 20, 5:00 p.m.-Reception hosted by Linda Hall Library Trustees.

Thursday, June 20, 7:00 p.m.-Dinner.

"The Antiquarian Book Trade in Our Time" -speaker to be announced.

Friday, June 21, 9:30 a.m.-"Antiquarian Book Trade in Great Britain, France, and The Germanies." Great Britain-
John J. Waldsdorf, American representative, Blackwell's, Oxford; France--Henk Edelman, chief bibliographer, Joint University Libraries, Nashville, Tennessee; The Germanies-Robert Caxden, professor of library science, University of Kentucky, Lexington.

Friday, June 21, 2:30 p.m.-“"Antiquarian Book Trade in Italy"-Mario Witt, antiquarian book dealer, Florence; "Spain and Scandinavia"-speakers to be announced.

Friday, June 21, 5:30 p.m.-Social hour hosted by H. P. Kraus, New York.

Friday, June 21, 7:00 p.m.-Dinner.

"Reminiscences of a Midwestern Antiquarian Bookseller,"-Richard F. Banta, antiquarian bookseller, Crawfordsville, Ind.

Saturday, June 22, 9:00 a.m.-Business meeting.

Saturday, June 22, 9:30 a.m.-“Antiquarian Book Trade in The Low Countries"Meno Hertzberger, antiquarian bookseller, Amsterdam; "The United States and Points South"-Joseph Rubinstein, antiquarian bookseller, Tucson, Ariz.

Saturday, June 22, 12:00 noon-Luncheon -Regional meeting of the Mississippi Valley Regional Group of the Bibliographical Society of America.

Resume and critique of the Rare Books Institute papers-Ellen Shaffer, Philadelphia Free Library.

Saturday, June 22, 2:00 p.m.

Manuscript librarians' mecting. "Private $\mathrm{Pa}-$ pers in Presidential Libraries"-Philip C. Brooks, Director, Harry S Truman Library, Independence, Mo.

\section{RSD HISTORY SECTION}

The RSD History Section of ALA (Felix E. Hirsch, Trenton State College, chairman) will devote its session at Kansas City to a topic of wide interest to academic librarians and to historians. Oscar $\mathrm{O}$. Winther, university professor of history at Indiana University, will give an address on "Immigrant Trains." Dr. Winther is a scholar of national reputation and an excellent speaker. His standard works "The Great Northwest," "Old Oregon Country," and "The Transportation Frontier" are in most academic libraries. His address will be followed by an extended discussion. ACRL members are cordially invited to attend this session on Wednesday, June 26, at 10 a.m. 


\section{We install libraries for colleges. Complete or à la carte.}

\section{Entire new libraries, or any part of a}

library if you're expanding. Bro-Dart is America's complete library source.

BOOKS: We are equipped to deliver books with 3 sat sets of Library of Congress cards or with cards and Lifetime Plasti-Kleer ${ }^{\circledR}$ book jacket covers.

CATALOGING AND PROCESSING: We can deliver books custom cataloged and processed according to your library's own specifications. And, if you are planning a model children's library for your teachers' college, Bro-Dart is ideally suited to handle this for you too.

COMPUTER-PROCESSED CENTRAL BOOK CATALOG: Through fast, accurate computer systems we can compile your collection catalog annually (register book and indexes) with supplements issued on whatever schedule is required.

FURNITURE: Bro-Dart manufactures complete lines of traditional and contemporary shelving, reading room furniture and card files in addition to our famous line of durable, rugged library workroom furniture.

CHARGING SYSTEMS: Bro-Dart makes three types of circulation systems. One of them is just right for your library requirements.

SUPPLIES: Bro-Dart is the nation's largest and most comprehensive manufacturer of library supplies including Lifetime Plasti-Kleer book jacket covers.

Whether you are planning a new library, expanding or renovating, contact Bro-Dart. Write Dept. CRL-41.

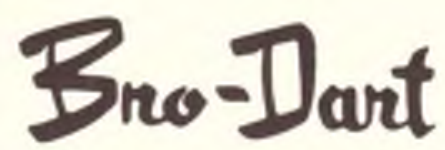

56 Earl Street, Newark, New Jersey 07114

Newark - Williamsport - Los Angeles - Brantford, Ontario 